Article

\title{
Impact of Nanoadditives on the Performance and Combustion Characteristics of Neat Jatropha Biodiesel
}

\author{
Abul Kalam Hossain * and Abdul Hussain \\ Sustainable Environment Research Group, School of Engineering and Applied Science, Aston University, \\ Birmingham B4 7ET, UK; abdul_369@hotmail.com \\ * Correspondence: a.k.hossain@aston.ac.uk; Tel.: +44-(0)-121-204-3041
}

Received: 27 December 2018; Accepted: 5 March 2019; Published: 10 March 2019

\begin{abstract}
Jatropha biodiesel was produced from neat jatropha oil using both esterification and transesterification processes. The free fatty acid value content of neat jatropha oil was reduced to approximately $2 \%$ from $12 \%$ through esterification. Aluminium oxide $\left(\mathrm{Al}_{2} \mathrm{O}_{3}\right)$ and cerium oxide $\left(\mathrm{CeO}_{2}\right)$ nanoparticles were added separately to jatropha biodiesel in doses of $100 \mathrm{ppm}$ and $50 \mathrm{ppm}$. The heating value, acid number, density, flash point temperature and kinematic viscosity of the nanoadditive fuel samples were measured and compared with the corresponding properties of neat fossil diesel and neat jatropha biodiesel. Jatropha biodiesel with $100 \mathrm{ppm} \mathrm{Al}_{2} \mathrm{O}_{3}$ nanoparticle (J100A100) was selected for engine testing due to its higher heating value and successful amalgamation of the $\mathrm{Al}_{2} \mathrm{O}_{3}$ nanoparticles used. The brake thermal efficiency of J100A100 fuel was about 3\% higher than for neat fossil diesel, and was quite similar to that of neat jatropha biodiesel. At full load, the brake specific energy consumption of J100A100 fuel was found to be $4 \%$ higher and $6 \%$ lower than the corresponding values obtained for neat jatropha biodiesel and neat fossil diesel fuels respectively. The NOx emission was found to be $4 \%$ lower with J100A100 fuel when compared to jatropha biodiesel. The unburnt hydrocarbon and smoke emissions were decreased significantly when J100A100 fuel was used instead of neat jatropha biodiesel or neat fossil diesel fuels. Combustion characteristics showed that in almost all loads, J100A100 fuel had a higher total heat release than the reference fuels. At full load, the J100A100 fuel produced similar peak in-cylinder pressures when compared to neat fossil diesel and neat jatropha biodiesel fuels. The study concluded that J100A100 fuel produced better combustion and emission characteristics than neat jatropha biodiesel.
\end{abstract}

Keywords: biofuel; CI engine; combustion; emission; greenhouse gas; jatropha biodiesel; nanoparticle; performance

\section{Introduction}

The amount of $\mathrm{CO}_{2}$ in the atmosphere has increased significantly since the start of the industrial era in the 18th century [1]. Fossil fuels used in the transportation and electricity (and heat) production sectors are responsible for about $40 \%$ of the total global greenhouse gas (GHG) emissions [2]. In the $\mathrm{UK}$, road transports are responsible for $22 \%$ of the total $\mathrm{UK} \mathrm{CO}_{2}$ emissions [3]. Use of renewable biofuels instead of fossil based fuels could reduce the GHG emissions significantly [4-6]. Biodiesels, produced through transesterification of seed oils (or wastes), have diesel like physico-chemical fuel properties and may substitute fossil based diesel fuel. They are biodegradable, has higher oxygen content and cetane number [7]. Engine performance and combustion characteristics were assessed by researchers using various biodiesels and their blends with fossil diesel [8,9]. The type of feedstock used for biodiesels production affect life cycle energy and GHG emission of the transesterification 
process. Hence, it is important what type of crops are used for biodiesel production such as edibles and non-edibles. This has led to controversy surrounding farmland and whether it should be used for food or fuel [6]. Mofijur et al. [10] studied the engine performance characteristics operated separately with biofuels obtained from edible and non-edible feedstocks. Two biodiesels, produced from palm (edible) and jatropha (non-edible) oils were used. They found that considering the overall emission reduction potential, jatropha biodiesel was better than palm biodiesel $[10,11]$.

The effects of various oxygenated additives on biofuels were investigated by the researchers to further improve the combustion and emission characteristics of the biofuels powered internal combustion (IC) engines. For example, nanoparticles were added to fuel mixtures to improve the engine performance and combustion characteristics; typically, metallic oxides nanoparticles were used to increase the heat release rate and thermal efficiency [12-14]. Metal-oxide nanoparticles have the ability to donate oxygen atoms to the fuel mixture and can create high surface to volume ratio; hence, they act as high reactive medium for combustion. Other advantages of adding nanoparticle additives are: increased thermal conductivity, flash point and fire point temperatures; and reduced kinematic viscosity $[12,13]$. The nanoparticle additives essentially behave like a catalyst. Due to high surface to volume ratio they are able to react more effectively, thus increasing the rate of fuel combusted $[14,15]$. Cerium oxide, aluminium oxide, cobalt oxide and zinc oxide are amongst the most popular nanoadditives due to their unique composition that aids in a more effective way of burning the fuel inside the engine cylinder [16-18]. Effective mixing of nanoparticles in the fuel mixture is important, literature reported that use of surfactant and ultrasonic machine helped to produce single phase nanoparticle fuel blend $[19,20]$.

Furthermore, studies demonstrated that addition of cerium oxide in the fuel has the ability to reduce in-cylinder pressure, this in turn causes a decrease in the NOx emissions; in addition, due to the catalytic soot combustion characteristics, cerium oxide has the added capacity to remove soot from the particulate filter [11,21]. Razek et al. [22] investigated the effects of nanoparticle additives on jatropha biodiesel (JBD)-diesel blends. They reported that blend containing $20 \% \mathrm{JBD}$ and $80 \%$ diesel with $\mathrm{Al}_{2} \mathrm{O}_{3}$ nanoadditives gave $12 \%$ increase in brake thermal efficiency (BTE) and $12.5 \%$ reduction in brake specific fuel consumption (BSFC). The authors reported that NOx emission was decreased by $13 \%$; emissions of unburnt hydrocarbon (UHC) and CO gases were reduced by $10 \%$ and $29 \%$ respectively [22]. Effects of nanoadditives on waste-derived biodiesels were also investigated. A significant reduction in $\mathrm{CO}, \mathrm{UHC}$ and NOx emissions were reported when poultry litter biodiesel-diesel-nanoparticle blend was used in the IC engine instead of the fuel blend without nanoparticles [23]. Compared to the fossil diesel fuel, up to $2 \%$ increase in engine power and $7.08 \%$ decrease in BSFC were observed when multi wall carbon nanotubes and nanosilver nanoparticles were added to the waste cooking oil biodiesel-diesel blends [24]. Nanoadditives enhanced the combustion characteristics of the pure fossil diesel powered engine. As a result of better combustion, the $\mathrm{CO}_{2}$ emissions increased by up to $17.03 \%$ and CO emissions decreased by $25.17 \%$ when compared to pure fossil diesel fuel operation [24]. Up to $8 \%$ reduction in BSFC was achieved when ferrofluid nanoparticles were added to pongamia biodiesel-diesel (B20) blends [25]. The authors reported that due to improved burning, the emissions of $\mathrm{CO}$ and UHC gases were also decreased when compared to non-additive fuel blends [25].

The thermal efficiency was improved by about $2.2 \%$ and emissions of $\mathrm{HC}, \mathrm{CO}$ and smoke were considerably decreased when copper oxide nanoparticles-mahua biodiesel-fossil diesel blends were used instead of B20 blend without nanoparticles [26]. Basha et al. [27] studied the combined effects of carbon nanotubes and diethyl ether additives on biodiesel emulsion fuels. They reported that additives gave better engine performance than pure biodiesel and pure fossil diesel [27]. In another study, carbon nanotube and ethanol was added to B2 fuel (B2E4C60) and observed a 15.52\% increase in engine power and $11.73 \%$ decrease in BSFC as compared to when the engine was operated with pure fossil diesel fuel [28]. The authors also found that due to the additives, the $\mathrm{CO}$ and UHC emissions were decreased by $5.47 \%$ and $31.72 \%$ respectively, but the NOx emissions increased by about $12.22 \%$ [28]. Approximately $7-20 \%$ and $15-28 \%$ reductions in CO and UHC gases were observed when graphene 
oxide nanoparticles were added to Ailanthus altissima biodiesel-diesel blends (B0, B10, and B20) [29]. Furthermore, the effects of nanoadditives on a thermal barrier coated engine were also investigated. A simulation study on a coated piston showed increased temperature distribution and reduced heat flux when compared to uncoated piston [30]. Due to the reduced heat flux, an improvement in thermal efficiency by $1.75 \%$ was observed on coated engine using Cymbopogon flexuosus biofuel-fossil diesel blends with $20 \mathrm{ppm}$ cerium oxide nanoadditive when compared to an uncoated engine using the same fuel [30]. In a separate study, Cymbopogon flexuosus biofuel (20\%)-fossil diesel (80\%) blends with various proportions of cerium oxide nanoadditives achieved up to $4.76 \%$ higher thermal efficiency and $6.6 \%$ decrease in smoke opacity as compared to biofuel-diesel blends without nanoadditives [31]. Addition of nanoparticles gave increased heat release rate and peak in-cylinder pressure; emissions of UHC, CO and NOx gases were reduced by $7 \%, 12.5 \%$ and $3 \%$, respectively, at full engine load. [31]. The literature reports that in a thermal barrier coated engine, the nitrogen oxides gases were increased and emissions of UHC, CO and smoke opacity were reduced. Carbon-coated aluminium additives were added in biodiesel-diesel-ethanol blends and tested in a diesel engine to assess the engine performance and emission characteristics; the study found that B10 blend with $4 \%$ ethanol and $30 \mathrm{ppm}$ nanoparticles reduced both BSFC and NOx emissions by about $6 \%$ when compared to B10 fuel (without ethanol and nanoparticles) [32]. However, the authors reported that compared to B10 fuel, the particles number (PN) emissions were increased by 2.2 times for B10-ethanol-nanoparticles fuel; on the contrary, this was decreased by about $11.8 \%$ for B10-ethanol fuel [32].

Up to $12 \%$ improvement in BTE, $30 \%$ reduction in NO emission, $60 \%$ reduction in CO emission, $44 \%$ reduction in UHC emission and 38\% reduction in smoke emission were observed when both cerium oxide and alumina nanoadditives was added to B20 jatropha biodiesel blend as compared to B100 fuel [33]. Ignition delay was affected when nanoadditives were used in the fuel. Jatropha biodiesel emulsion fuel (83\% jatropha biodiesel, 15\% water, and 2\% surfactants (Span80 and Tween 80 )) mixed with aluminium nanoparticles gave lower ignition delay, better engine performance and reduced emissions compared to pure jatropha biodiesel or jatropha biodiesel emulsion [19]. Another study reported that the ignition delay was deceased by about $9 \%$ when carbon nanotube and Ag nanoparticles were added to jojoba biodiesel-diesel blends [34].

Jatropha oil (JCO) is derived from the Jatropha curcas plant, they can be grown in unfarmable lands and can endure adverse weather conditions. Non-edible oils are the most appropriate feedstock for biodiesel production as they do not put a strain on global food demand [35]. However, the concern with non-edible feed stocks is that some crops have a high Free Fatty Acid value (FFA). The FFA value determines whether or not the oil needs to undergo an additional process (ie. esterification) before transesterification. The esterification process or 'pre-treatment' makes biodiesel production a two-step process capable of producing a high yield of fuel in a relatively short amount of time [36]. Jatropha carcus trees are grown in many parts of India and in Africa. Use of 100\% biodiesel (B100) would provide much more emission reduction benefits than using biodiesel-diesel blends. Most studies found in the literature reported effects of nanoparticles on jatropha biodiesel-diesel blends. The aim of the current study is to investigate the performance, combustion and emission characteristics of a multi-cylinder diesel engine operated with nanoparticles-100\% jatropha biodiesel fuel mixture. Initial findings of the study have been presented at the 13th SDEWES conference [37]. Two nanoparticles cerium oxide and aluminium oxides will be used in this study. Jatropha biodiesel will be produced in the lab using two stages, i.e., esterification and transesterification. Nanoadditives-J100 fuel blends will be tested in a multi-cylinder engine. The specific objectives of this study are:

- Pre-treatment of jatropha oil and production of jatropha biodiesel

- Amalgamation of nanoparticle additives into jatropha biodiesel

- Measurement of physico-chemical properties of various fuel blends

- Engine testing using nanoparticle-J100 blend and assessment of combustion, emission and performance characteristics

- Comparison of results with and without nanoparticles and recommendations 


\section{Materials and Methods}

\subsection{FFA Determination and Pre-Treatment (Acid Esterification) of JCO}

Typically, biodiesel feedstocks that have a FFA value below $2 \%$ can be converted into biodiesel through a single step process known as transesterification. However, if the FFA content is $>2 \%$ than the additional process (i.e., esterification) is required. Jatropha oil was produced in Ghana and collected from a UK supplier. Isopropanol, $\mathrm{H}_{2} \mathrm{SO}_{4}$, methanol, phenolphthalein $1 \%$ and potassium hydroxide $(\mathrm{KOH})$ were purchased from Sigma-Aldrich (Dorset, UK). An acid base titration method (using $\mathrm{KOH}$ ) was used to determine the FFA content present in JCO. Alcohol to oil ratio, temperature and reaction time are important parameters for esterification process [38,39]. The formulae used by Heroor and Bharadwaj [38] was used to calculate the FFA content (in \%) of the jatropha oil and biodiesel. The most favorable esterification process ascertained for the jatropha oil were: using a methanol to oil (molar) ratio of $6: 1$, with a $\mathrm{H}_{2} \mathrm{SO}_{4}$ catalyst concentration of $0.5 \%$, reaction time of 45 min whilst maintaining the temperature of $40 \pm 5{ }^{\circ} \mathrm{C}$ [40]. Esterification of jatropha oil was conducted using $5 \% \mathrm{H}_{2} \mathrm{SO}_{4}$ and $20 \%$ methanol at a steady temperature of $65^{\circ} \mathrm{C}$ [41]. Tiwari et al. [42] reported that for esterification of jatropha oil, a methanol to oil ratio of $0.28: 1(v / v)$ should be used with a catalyst concentration of $1.43 \%$, along with a reaction time of $88 \mathrm{~min}$ at $60^{\circ} \mathrm{C}$ temperature. Based on the above literature and laboratory trials, following methods were applied for esterification of JCO:

- JCO was poured into a flask, placed on to a hot plate and heated up to $60^{\circ} \mathrm{C}$

- Methanol with a ratio of $60 \%(\mathrm{w}: \mathrm{w})$ of methanol to oil, was taken into another beaker. After that $1 \% \mathrm{H}_{2} \mathrm{SO}_{4}$ was added to the methanol beaker. The methanol and $\mathrm{H}_{2} \mathrm{SO}_{4}$ mixture was stirred for approximately $5 \mathrm{~min}$ before adding the solution to the $60^{\circ} \mathrm{C}$ heated JCO. Once mixed, the solution was left on the hotplate stirrer for about $90 \mathrm{~min}$ at a temperature of $55 \pm 5^{\circ} \mathrm{C}$

- The esterified solution was then poured into a separation funnel and left for 2 hours. The top layer was waste water and methanol, the bottom layer was esterified JCO

\subsection{Transesterification}

The FFA content in pre-treated JCO (i.e., esterified JCO) was measured again by the titration procedure in order to make sure that the FFA value is below $2 \%$. Literature reported effective transesterification of JCO by using a methanol to oil (molar) ratio of 9:1, and with a $\mathrm{KOH}$ catalyst of $0.5 \%$ [40]. In another study, the recommended amount of catalyst suggested is between $0.1 \%$ to $1 \%$ $(w / w)$ of oils [43]. Furthermore, another literature reported that the molar ratio of methanol to oil at $6: 1, \mathrm{NaOH}$ concentration of $0.7 \%(w / w)$, and reaction temperature of $65^{\circ} \mathrm{C}$ was found to be effective for the transesterification of JCO [41]. The optimum parameters for the transesterification of JCO were ascertained by implementing: (i) a methanol to oil ratio of $0.16(v / v)$, and (ii) a constant temperature of $60{ }^{\circ} \mathrm{C}$. The $\mathrm{KOH}$ was used as a catalyst.

\subsection{Addition of Nanoparticles to Neat Jatropha Biodiesel}

Jatropha biodiesel was produced in the lab (Sections 2.1 and 2.2); nanoparticles $\mathrm{Al}_{2} \mathrm{O}_{3}$ and $\mathrm{CeO}_{2}$, and surfactant Triton X-100 were purchased from Sigma-Aldrich. A GT Sonic ultrasonicator (Shenzhen, China) was used for mixing the nanoparticles in biodiesel-surfactant mixture. Quantities of $50 \mathrm{ppm}$ and 100 ppm of nanoparticles were added to neat jatropha biodiesel (J100). The following method was adapted for nanoparticles addition into neat biodiesel:

- 1000 ppm of Triton-X100 was added to J100

- Either 50 ppm or 100 ppm of $\mathrm{CeO}_{2} / \mathrm{Al}_{2} \mathrm{O}_{3}$ nanoparticles were added to $\mathrm{J} 100$ mixture to produce four samples: J100C50 and J100C100 with $\mathrm{CeO}_{2}$ additives; J100A50 and J100A100 with $\mathrm{Al}_{2} \mathrm{O}_{3}$ additives (Figure 1) 
- Biodiesel-nanoparticles mixtures were placed in an ultrasonicator (frequency at $40 \mathrm{kHz}$ and water at $45^{\circ} \mathrm{C}$ ) for a duration of $45 \mathrm{~min}$. After that the samples were left for $72 \mathrm{~h}$ at room temperature to see the stability of the mixture

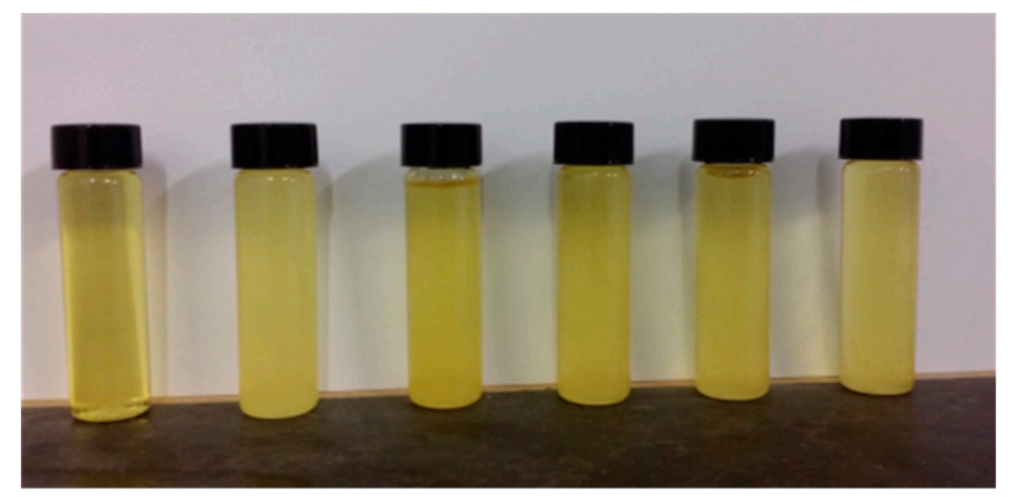

Figure 1. Fuel samples (from left to right): Diesel, J100, J100A100, J100A50, J100C100 and J100C50.

\subsection{Characterisation of Fuel Samples}

Crucial properties that are vital to the fuel's performance in engine and exhaust emissions were measured in the lab. A Parr 6100 bomb calorimeter (Parr Instrument Company, Moline, IL, USA) was used to measure the higher heating value (HHV) in accordance to ASTM-D240 standard. Canon Fenski u-tube viscometers (CANON Instrument Company, State College, PA, USA) and thermostatic water bath $\left( \pm 0.1^{\circ} \mathrm{C}\right)$ was used to measure the kinematic viscosities according to ISO 3104 having an accuracy of $\pm 0.22 \%$. Viscosity was measured at temperatures of $40{ }^{\circ} \mathrm{C}$ and $22{ }^{\circ} \mathrm{C}$. The densities were measured using a hydrometer in accordance to ISO 3675 standard. Flash point temperatures were measured using a Setaflash series 3 plus closed cup flash point tester (model 33000-0, STAN-HOPE SETA, UK). The test methods used were in compliance with DIN EN 22719, a part of the EN14214 standard. The acid value was measured using the same technique used for FFA measurement [30].

\subsection{Engine Testing}

A model LPWSBio3 three cylinder engine manufactured by Lister Petter (Teignmouth, UK) was used in the investigation (Table 1). An eddy current Froude AG80HS dynamometer (Froude Ltd., Worcester, UK) was used to measure and adjust the engine load and speed (Figure 2). The torque and speed accuracies of the dynamometer are $\pm 0.4 \mathrm{Nm}$ and $\pm 1 \mathrm{rpm}$ respectively. A five-gas emission analyser BEA 850 (Robert Bosch Ltd., Middlesex, UK) and smoke opacity meter (Bosch RTM 430) was used to analyse the exhaust gas components $\left(\mathrm{CO}, \mathrm{CO}_{2}, \mathrm{NOx}, \mathrm{O}_{2}\right.$ and $\left.\mathrm{UHC}\right)$ and to measure the smoke intensity respectively. The resolution for $\mathrm{CO}, \mathrm{CO}_{2}, \mathrm{NOx}, \mathrm{O}_{2}$ and $\mathrm{UHC}$ measurements are $0.001 \%$ vol., $0.01 \%$ vol., $1 \mathrm{ppm}$ vol., $0.01 \%$ vol. and $1 \mathrm{ppm}$ vol. respectively. The absorption coefficient resolution for the smoke meter is $0.01 \mathrm{~m}^{-1}$. Ratio of air to fuel was also measured using the same emission analyser. A LabVIEW data acquisition system was used to log the temperatures at different locations of the engine. Combustion characteristics were evaluated using a Kistler combustion analyser. A pressure sensor (6125C11, Kistler Instruments Ltd., London, UK) and charge amplifier (Kistler 5064B11) was used to measure pressure inside the cylinder. Another pressure sensor (Kistler 4065A500A0) and amplifier (Kistler 4618A0) was used to measure the fuel line injection pressure. An optical encoder (Kistler 2614A) was used for detection of the crank angle position. The amplifiers and the encoder electronics were connected to the 'KiBox' (Kistler, model 2893AK8) for data logging. The KiBoxCockpit software (Kistler Instruments Ltd., London, UK) was used to measure and analyse various combustion parameters such as in-cylinder pressure, $\mathrm{P}-\mathrm{V}$ diagram, heat release rate, combustion duration etc. 
Table 1. Specifications of the engine used in the experiment.

\begin{tabular}{cc}
\hline Model/Type & LPWS Bio3 Water Cooled \\
\hline No. of cylinders & 3 \\
Rated speed & $1500 \mathrm{rpm}$ \\
Continuous power at rated speed & $9.9 \mathrm{~kW}$ \\
Type of fuel injection & Indirect injection with individual fuel injection pumps \\
Fuel pump injection timing & $20 \_\mathrm{BTDC}$ \\
Exhaust gas flow & $3.19 \mathrm{~L} / \mathrm{h}($ fossil diesel) \\
Continuous power fuel consumption at $1500 \mathrm{rpm}$ & $41.4 \mathrm{~L} / \mathrm{s}$ at full loads at $1500 \mathrm{rpm}$ \\
\hline
\end{tabular}

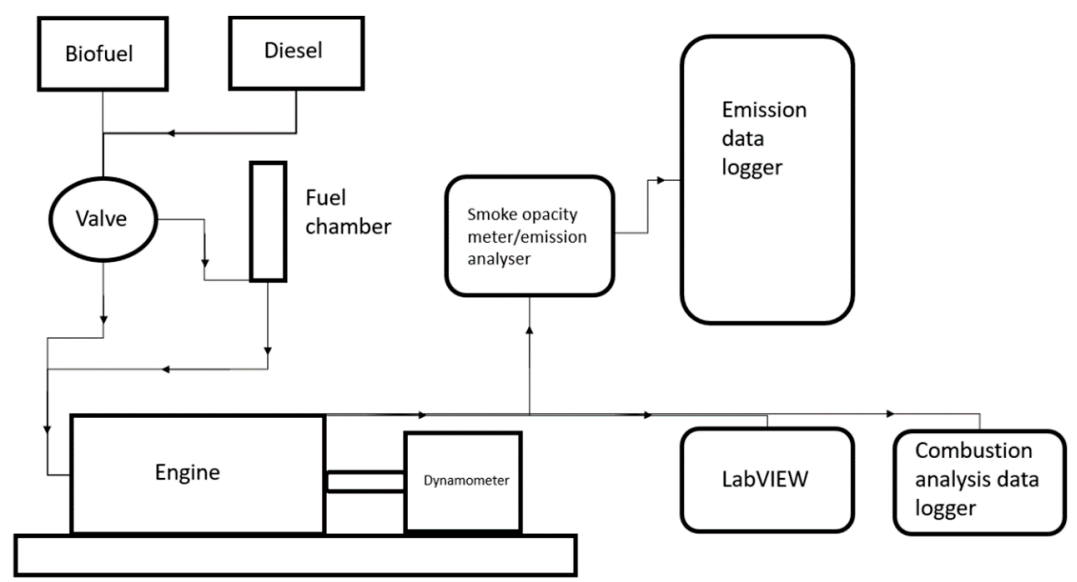

Figure 2. Schematic diagram of the engine test rig.

Fossil diesel, neat jatropha biodiesel (J100) and neat jatropha biodiesel with aluminium nanoparticles were tested in the engine. The engine was first operated with fossil diesel, then switched to neat jatropha biodiesel, and then finally operated with jatropha biodiesel-nanoparticle blend. The engine was operated at constant speed of $1500 \mathrm{rpm}$. For each test fuel, the engine was tested at six (6) different loads starting from low to full engine load. Once all data were measured and recorded at one load, the engine was ramped up to the next load using the dynamometer. At the end of test, the engine was switched back to fossil diesel and operated for about $15 \mathrm{~min}$ before stopping the engine.

\section{Results and Discussion}

\subsection{Nanoparticles Addition and Fuel Characteristics}

Through visual observation it was found that the $\mathrm{Al}_{2} \mathrm{O}_{3}$ nanoparticles had fully dissolved into their biodiesels and there was no sedimentation present. On the other hand, $\mathrm{CeO}_{2}$ nanoparticles did not dissolved completely and some sedimentation was seen at the bottom of the container for both $50 \mathrm{ppm}$ and $100 \mathrm{ppm}$ doses. Hence, blend containing $\mathrm{Al}_{2} \mathrm{O}_{3}$ nanoparticles was chosen for engine testing due to having better diffusion characteristics. The failure of the $\mathrm{CeO}_{2}$ not mixing fully was perhaps due to the type of surfactant used. Other surfactant such as Span 80 and Tween 80 might help to blend $\mathrm{CeO}_{2}$ nanoparticles with J100 fuel [44].

The results given in Table 2 demonstrate that the properties of J100 with or without nanoparticles mostly comply with the EN14214 standard. The properties of the J100 biodiesel was similar to the properties reported in the literature [41]. Density of J100 and jatropha-nanoadditive blends were higher than that of fossil diesel. Greater fuel density would allow for more fuel to be pumped via the fuel line, and greater mass of the fuel can be stored in a tank [40]. The EN14214 standard states that all biodiesel fuels must have acid value lower than $0.50 \mathrm{mg} \mathrm{KOH} / \mathrm{g}$, it had been observed that all fuel samples except JCO were able to achieve this value. Due to the addition of both surfactant and nanoparticles, the heating values of the nanoadditive fuel blends samples were slightly lower than that of neat jatropha biodiesel. 
Table 2. Measured properties of the test fuels.

\begin{tabular}{cccccccccc}
\hline Property & Units & $\begin{array}{c}\text { Neat } \\
\text { Diesel }\end{array}$ & $\begin{array}{c}\text { Jatropha } \\
\text { Curcas } \\
\text { Oil (JCO) }\end{array}$ & $\begin{array}{c}\text { Jatropha } \\
\text { Biodiesel } \\
\text { (J100) }\end{array}$ & J100C50 & J00C100 & J00A50 & $\begin{array}{c}\text { J00A100 } \\
\text { Standards } \\
\text { (Biodiesel) }\end{array}$ \\
\hline Acid Value & $\mathrm{mg} \mathrm{KOH/g}$ & 0.34 & 13.59 & 0.45 & 0.28 & 0.20 & 0.20 & 0.20 & $<0.50$ \\
Flash point & ${ }^{\circ} \mathrm{C}$ & 63.6 & 181.8 & 171.2 & 174.8 & 177 & 173.6 & 175.6 & $>101$ \\
Density & $\mathrm{Kg} / \mathrm{m}^{3}$ & 832.3 & 922.6 & 881.6 & 880 & 879 & 877 & 878 & $860-900$ \\
Viscosity at $22^{\circ} \mathrm{C}$ & $\mathrm{CSt}$ & 3 & 75.57 & 4.73 & 5.92 & 6.23 & 6.03 & 5.95 & $\mathrm{~N} / \mathrm{A}$ \\
Viscosity at $40^{\circ} \mathrm{C}$ & $\mathrm{cSt}$ & 2.13 & 37.47 & 3.37 & 3.99 & 4.08 & 4.11 & 4.07 & $>3.5-5.0$ \\
$\mathrm{HHV}$ & $\mathrm{MJ} / \mathrm{kg}$ & 45.64 & 39.39 & 37.54 & 37.39 & 37.29 & 37.27 & 37.34 & $\mathrm{~N} / \mathrm{A}$ \\
\hline
\end{tabular}

\subsection{Engine Performance and Emission Characteristics}

Pure fossil diesel, J100 and J100A100 fuels were tested in the engine. In general, the bsfc for fossil diesel operation was found to be lower than those obtained for J100 and J100A100 fuels (Figure 3). The reason why J100 and J100A100 had higher BSFC values was owed to the fact they both had higher density values and lower calorific values when compared to corresponding values for fossil diesel.

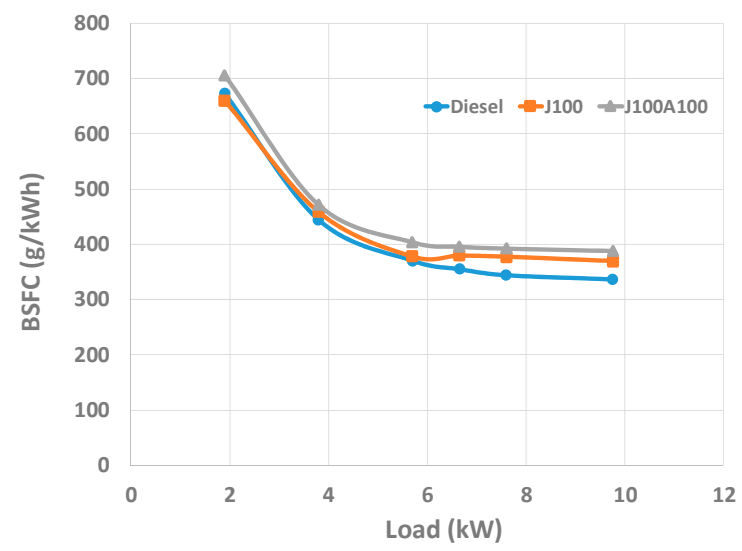

Figure 3. BSFC vs. engine load.

At about $3.8 \mathrm{~kW}$ engine load, the BSFC of the fossil diesel was $6 \%$ lower than that of J100A100 fuel. However, on average, a difference of 3\% in BSFC was observed between J100 and J100A100 fuels. At $9.75 \mathrm{~kW}(100 \%)$ load, the BSFC of J100A100 was about 13\% higher than that of fossil diesel; on the other hand, the BSFC of J100 was 4.5\% lower when compared to J100A100 fuel (Figure 3). On the contrary, it was observed that the brake specific energy consumption (BSEC) value of the J100A100 fuel was lower than that of fossil diesel throughout all load range (Figure 4). At full load, BSEC of the J100A100 fuel was found to be decreased by approximately $6 \%$. This explains that when the engine was operated with J100A100 fuel, comparatively less energy was required to produce the same power output as compared to fossil diesel operation.

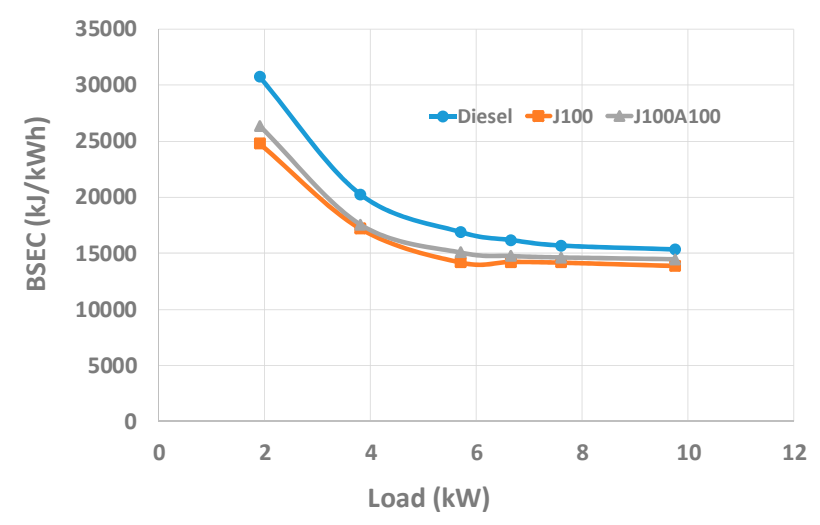

Figure 4. BSEC vs. engine load. 
The brake thermal efficiency (BTE) of J100 and J100A100 fuels were higher than the corresponding values observed for fossil diesel (Figure 5). At $20 \%$ engine load (1.9 kW), the BTE values for fossil diesel, J100 and J100A100 fuels were respectively $11 \%, 14.52 \%$ and $13.65 \%$. A higher BTE value for the biodiesel-nanoparticle blend might be attributed to a higher oxygen content present in the biodiesel and higher reactivity of the fuel mixture due to the nanoadditives $[14,18]$. On average, the BTE values of J100A100 fuel was about 3\% higher than that of fossil diesel. At higher loads, the thermal efficiency of J100 was observed to be slightly higher than those obtained for J100A100 fuel. Higher viscosity of J100A100 fuel might have caused this characteristic. At higher loads, the volume of carbon monoxide (CO) produced by the biodiesel-nanoparticle blend was found to be higher than that of fossil diesel (Figure 6); on the contrary, opposite characteristic was observed at lower loads. It was believed that higher BSFC value and higher oxygen content in the J100A100 fuel caused higher CO emissions at higher loads. Similarly, at higher loads, the $\mathrm{CO}_{2}$ emission of J100A100 fuel was found to be slightly higher than fossil diesel due to the higher BSFC value and higher oxygen content (Figure 7). The amount of UHC produced by the biodiesel blend was found to be lower than that of regular diesel (Figure 8). This was due to the fact that in the case of biodiesel-nanoparticles blend, more complete combustion took place inside the cylinder. It was observed that better combustion characteristics of the nanoadditive blend led to higher BTE (Figure 5). The J100A100 blend had the aid of an increased catalytic effect which helped in improving the overall combustion [14].

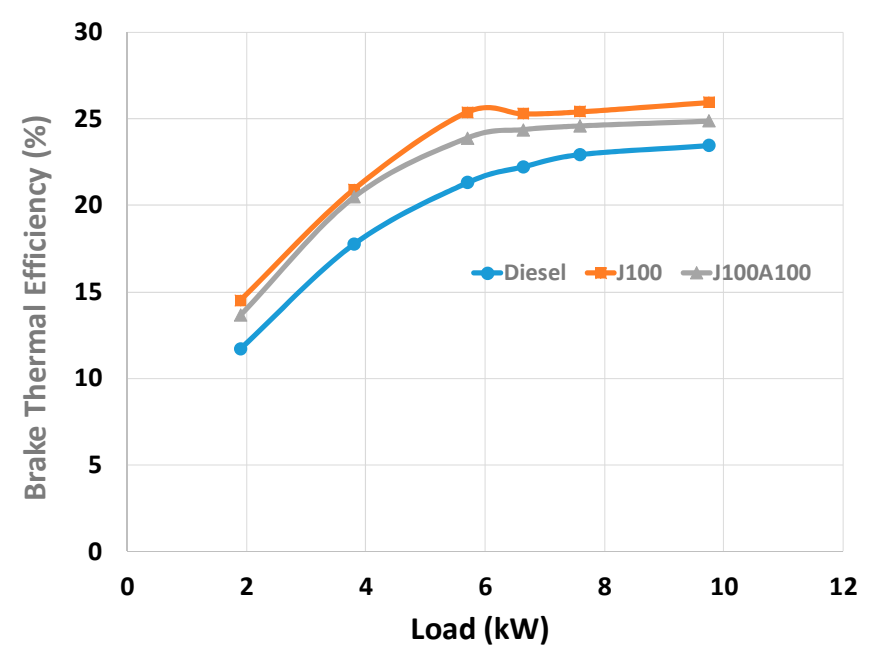

Figure 5. Brake thermal efficiency (BTE) vs. engine load.

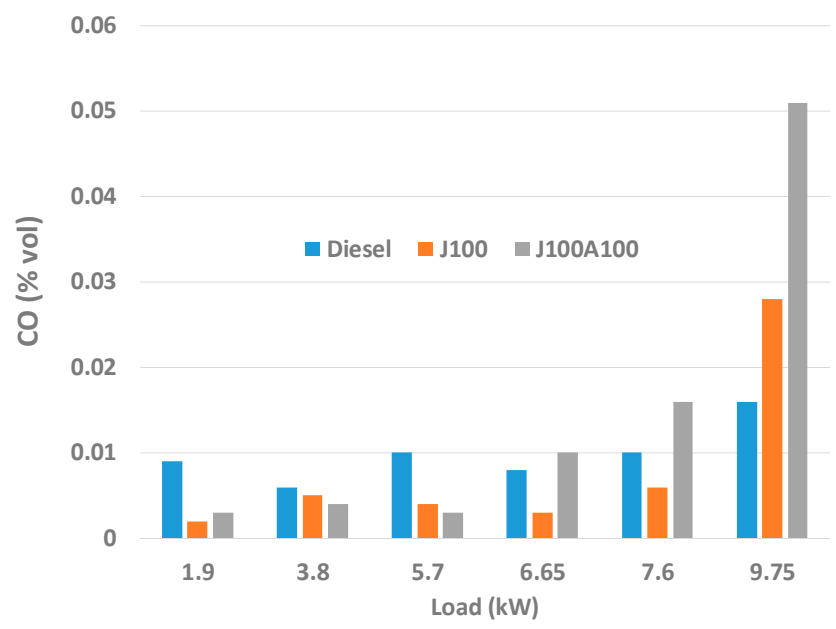

Figure 6. CO emission vs. engine load. 


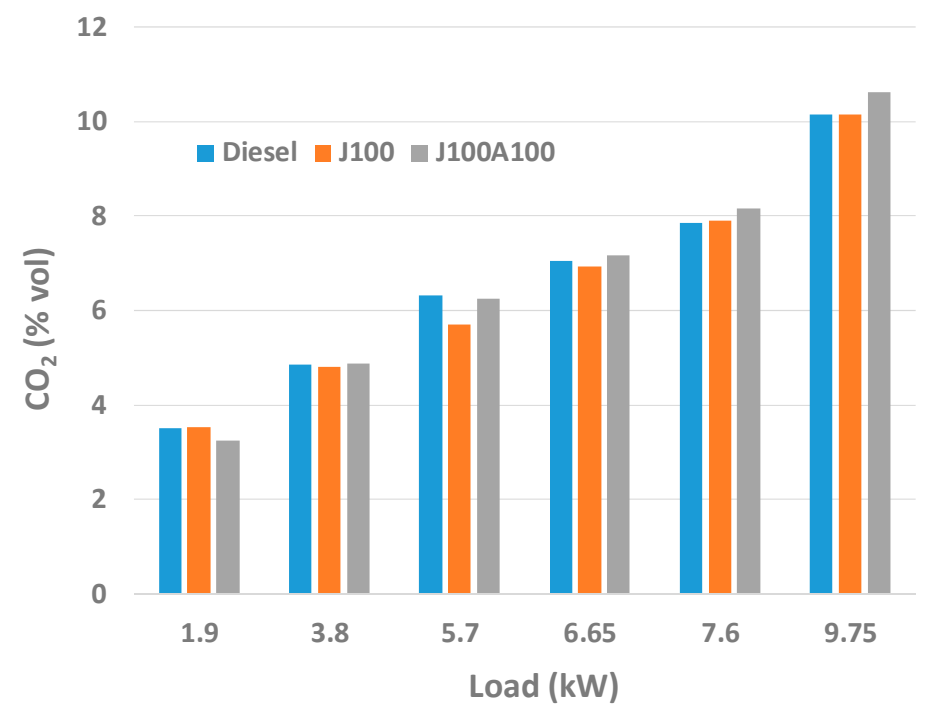

Figure 7. $\mathrm{CO}_{2}$ emission vs. engine load.

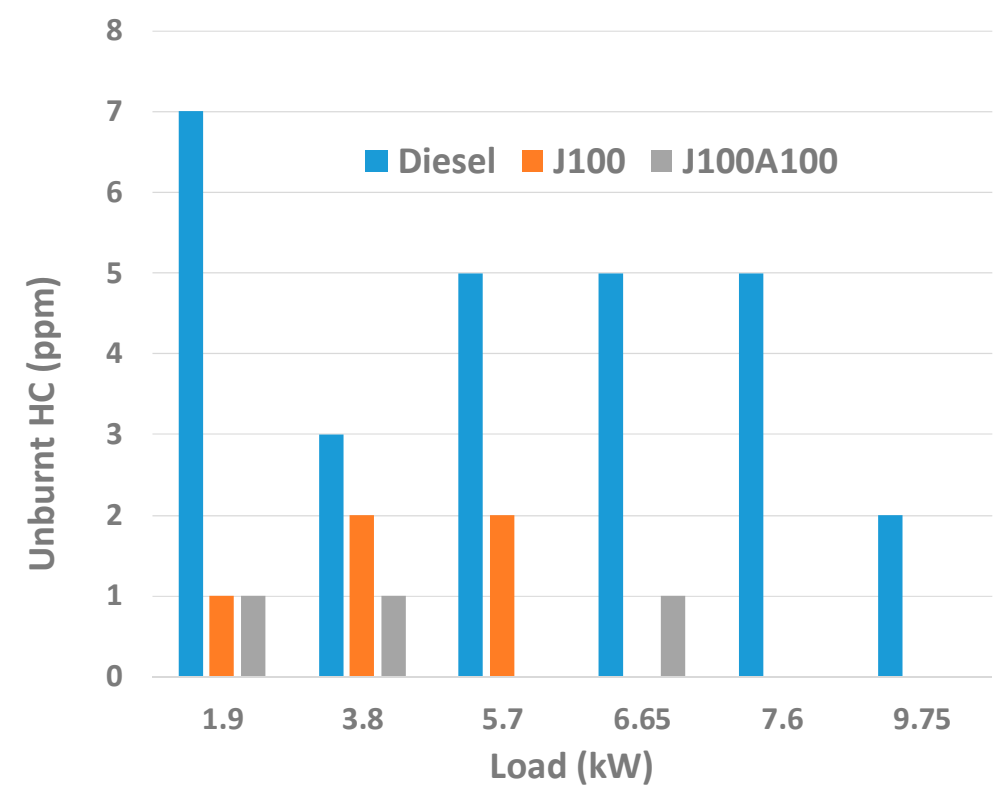

Figure 8. UHC emission vs. engine load.

It was observed that the J100 and J100-nanoparticle blend produced a greater amount of nitrogen oxide (NOx) emissions when compared to fossil diesel (Figure 9). Biodiesels intrinsically containing a greater amount of double bond molecules caused a higher adiabatic flame temperature which in turn leads to a greater concentration of NOx emissions. In the case of nanoparticle blends, an increase in combustion temperature caused due to a greater rate of reaction and conversion of the oxygen present in the nanoparticle blend led to an increased rate of NOx emissions [33]. Under most engine loads, the NOx emissions of J100 were higher than those of J100A1000 fuel. The reason for this was due to the catalytic nature of the nanoparticles present in the J100A1000 fuel, the nanoadditives broken down hydrocarbon compounds before they were able to become fully formed products [23]. The smoke opacity values for both pure biodiesel and biodiesel-nanoparticle blend were found to be much lower than those observed for fossil diesel (Figure 10). Oxygen content of the test fuel plays a significant role in the formation of smoke [45]. Better combustion due to higher oxygen content caused lower smoke levels in the case of nanoparticle-biodiesel blend [46,47]. When comparing between J100 and J100A100 fuels, it was observed that J100A100 had a lower smoke opacity values because of the greater amount of oxygen present (aided by the $\mathrm{Al}_{2} \mathrm{O}_{3}$ nanoadditive) in the J100A100 fuel. 


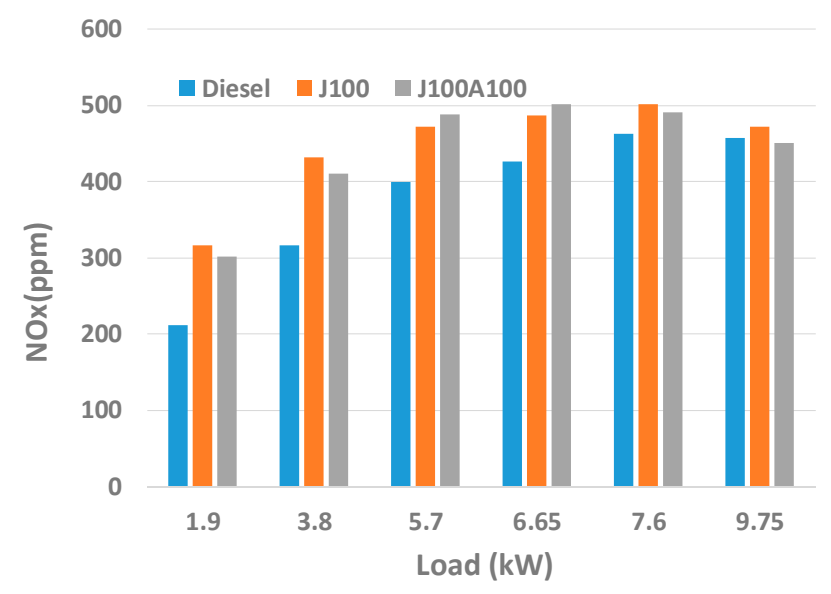

Figure 9. NOx emission vs. engine load.

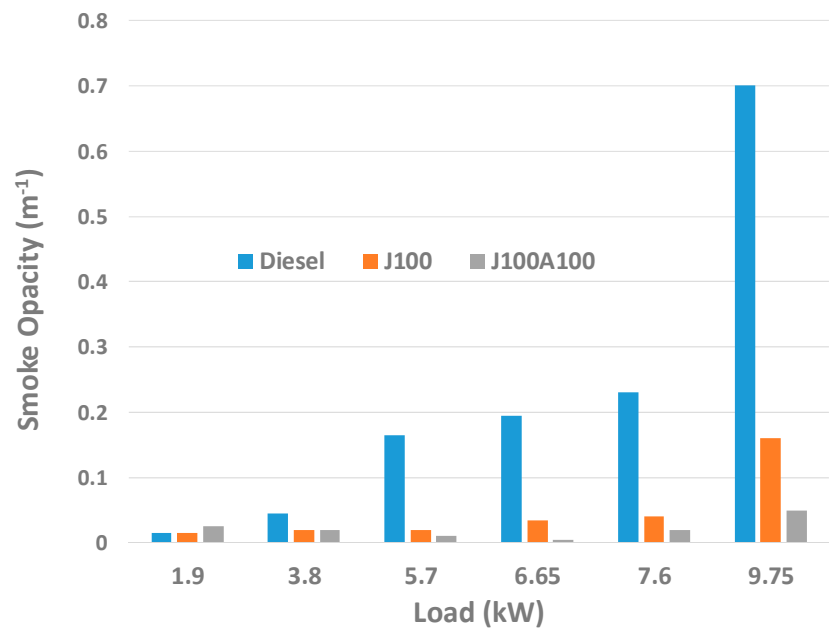

Figure 10. Smoke opacity vs. engine load.

\subsection{Combustion Characteristics}

Figures 11 and 12 shows in-cylinder pressures for all test fuels at $60 \%$ and $100 \%$ loads respectively. In general, increase in the in-cylinder pressures were observed with the increase in engine loads (Figures 11 and 12). At 60\% engine load (Figure 11), the charge temperature was low, lower charge temperature lengthened the ignition delay period [48]. At 100\% load (Figure 12), more fuel was injected into the chamber which caused the gas and wall temperatures to increase, this in turn reduced the ignition delay period. The peak in-cylinder pressures were occurred almost at the same crank angle location for all fuels. The fossil diesel gave highest peak in-cylinder pressure at $60 \%$ load; however, at $100 \%$ load, the peak in-cylinder pressures were almost equal for all fuels.

The heat release rates for both $60 \%$ and $100 \%$ engine loads are shown in Figures 13 and 14 . At 60\% load (Figure 13), the peak of heat release rate for fossil diesel was much higher than other fuels. The J100A100 fuel produced lowest peak heat release rate; this was caused due to the longer ignition delay period of J100A100 fuel when compared to fossil diesel and J100 fuels. The lower viscosity and better volatility traits of pure diesel fuel enabled to produce highest peak heat release rate at $60 \%$ engine load [17]. However, at 100\% load (Figure 14), peaks for both pure diesel and J100A100 fuels were almost the same; this combustion characteristic suggested that at higher temperatures, the nanoadditive fuel blend were not as volatile, and not enough fuel mixture is formed in the premixed burning phase. The total heat release values at $60 \%$ and $100 \%$ loads are demonstrated in Figures 15 and 16. At $60 \%$ load (Figure 15), amongst all fuels, J100A100 gave highest amount of total heat release; which suggested that once burning started, nanoadditive fuel burnt quite quickly relative to other fuels. The oxygen donated by the nanoparticles aided accelerated burning of the J100A100 fuel [49]. 
It was observed that the total heat release values for all test fuels were almost same at $100 \%$ load (Figure 16). This might be attributed to the absorption of heat by high heat capacity gases such as $\mathrm{CO}_{2}$, whose concentration increases with the increase of engine load. These gases absorb a fragment of the amount of total heat release which caused the J100 and its blend to follow a same trend [50], as demonstrated in Figure 16.

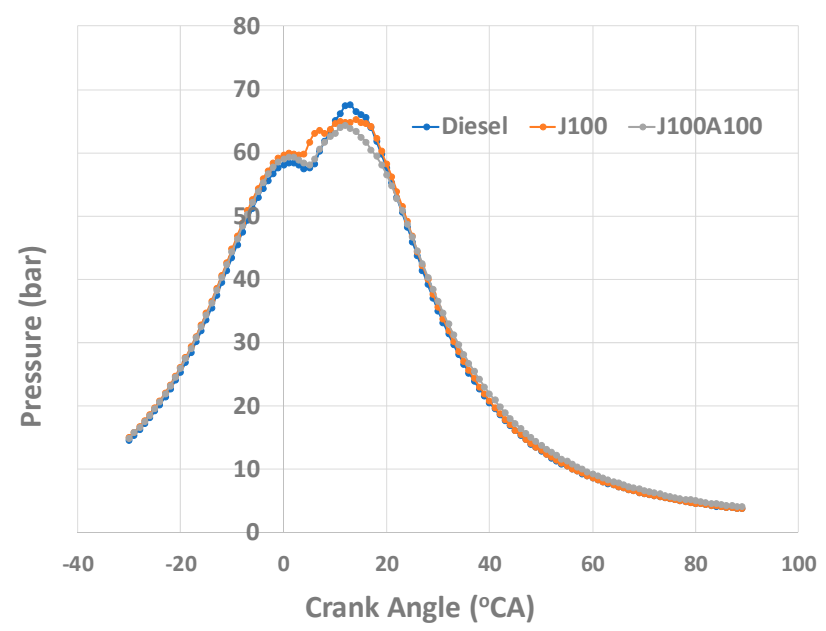

Figure 11. Cylinder pressure at $60 \%$ load.

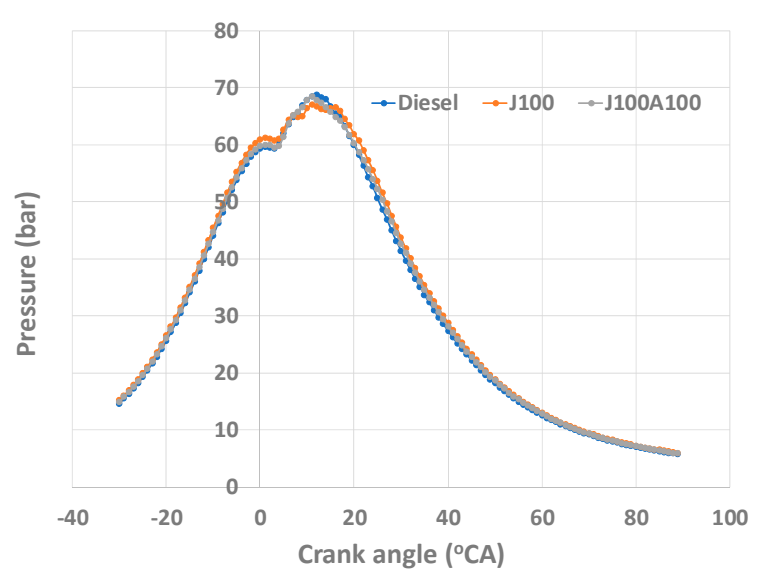

Figure 12. Cylinder pressure at $100 \%$ Load.

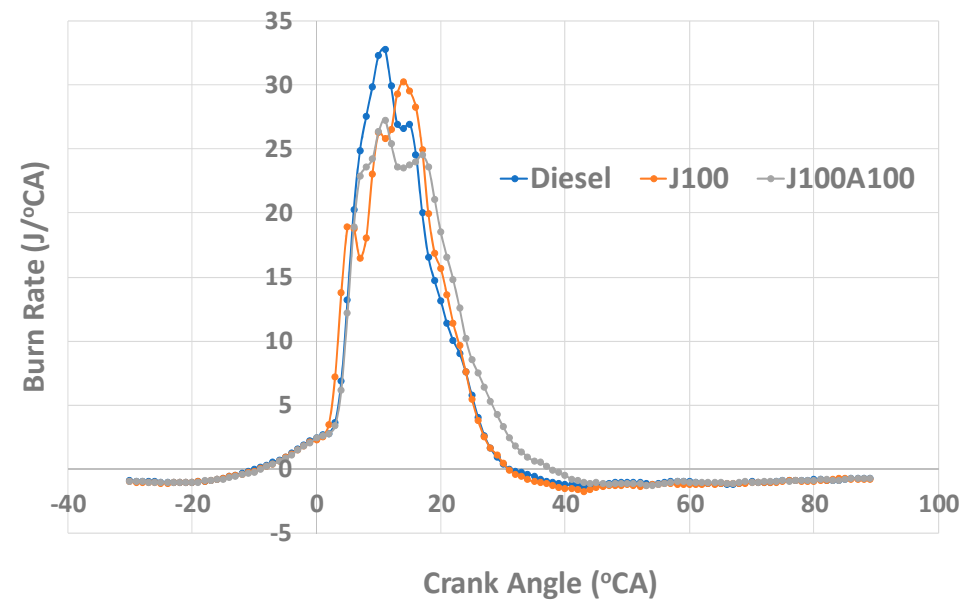

Figure 13. Heat release rate at $60 \%$ load. 


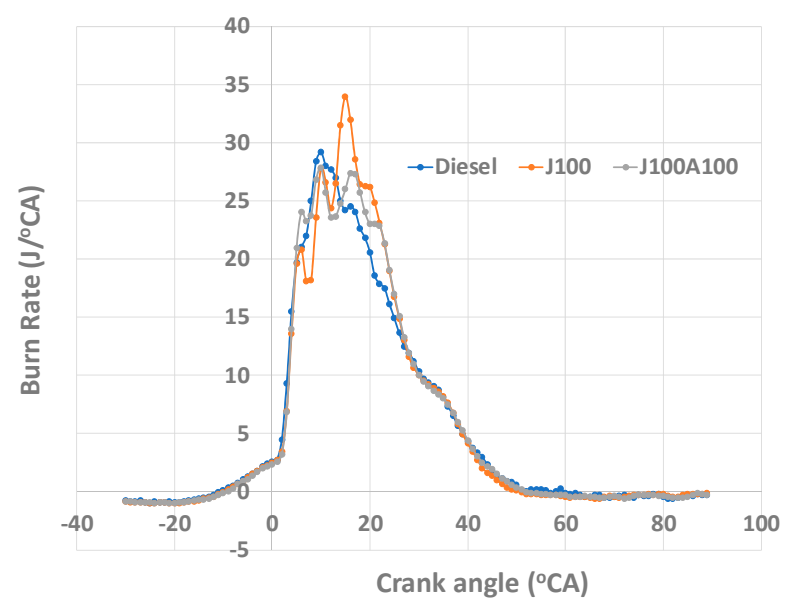

Figure 14. Heat release rate at 100\% load.

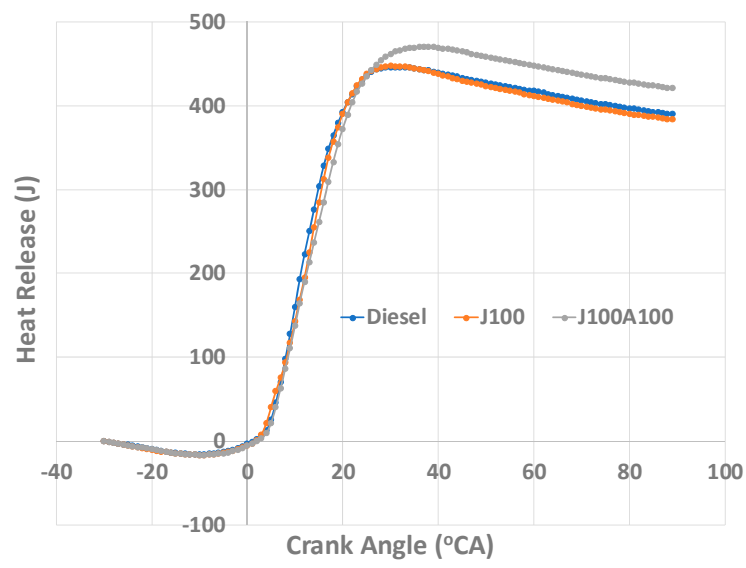

Figure 15. Total heat release at $60 \%$ load.

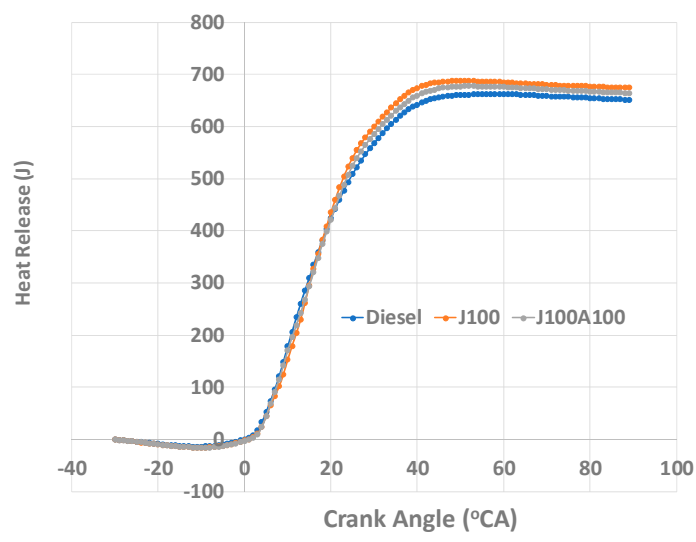

Figure 16. Total heat release at 100\% load.

\section{Conclusions and Recommendations}

Jatropha biodiesel was produced using both esterification and transesterification processes. The addition of $\mathrm{Al}_{2} \mathrm{O}_{3}$ and $\mathrm{CeO}_{2}$ nanoparticles to pure jatropha biodiesel was carried out by using an ultrasonicator device and surfactant Triton X-100. It was observed that the surfactant decreased the calorific values of the fuel blends. The $\mathrm{CeO}_{2}$ nanoparticles failed to fully amalgamate with the jatropah biodiesel. For successful amalgamation of the $\mathrm{CeO}_{2}$ nanoparticles into $\mathrm{J} 100$ fuel, other surfactant such as Span 80 and Tween 80 might be effective instead of Triton X-100. The J1000A100 blend was observed as having promising characteristics that would aid in the fuel's performance when tested in the IC 
engine. Neat jatropha biodiesel and neat fossil diesel fuels were used as a control. The findings on engine performance, combustion and emission characteristics results are summarised below:

(1) At full load, the BSEC values of J100A100 blend was found to be $4 \%$ higher and $6 \%$ lower than the corresponding values obtained for J100 and neat fossil diesel fuels respectively. On the other hand, the BSFC value of J100A100 blend was found to be higher than fossil diesel; however, on average, an improvement of 3\% in BTE was observed for J100A100 fuel when compared to fossil diesel.

(2) At low loads, J100A100 fuel gave lower amount of CO emissions. On the other hand, in almost all loads, J100A100 produced smallest amount of UHC emission due to the rich oxygen content in the nanoadditive fuel blend. At higher loads, J100A100 fuel gave improved NOx emission characteristics when compared to J100 fuel.

(3) Better combustion due to nanoadditives led to least smoke opacity values when the engine was operated with J100A100 fuel. The J100A100's combustion characteristics helped display and measure the fuel's performance in the combustion chamber. The peak in-cylinder pressure for J100A100 fuel at 60\% engine load was seen as being lowest when compared to other fuels; however, this trend was changed when the engine load was increased. At $100 \%$ load, the peak in-cylinder pressures for all three fuels were almost same.

(4) At $60 \%$ and $100 \%$ loads, the J100A100 blend was observed as having a constant heat release rate, this was attributed to the additives ability to provide a constant burn and not to succumb to volatility. The total heat release was found to be higher at $60 \%$ load for the J100A100 fuel; however, at $100 \%$ load, this value was equal to those obtained for other fuels.

To conclude, overall $\mathrm{J} 100-\mathrm{Al}_{2} \mathrm{O}_{3}$ nanoadditive fuel performed better when compared to fossil diesel and J100 fuels. A reduction in NOx and UHC emission as well as smoke opacity, and an overall increase in BTE were observed when compared to J100 fuel. Effect of nanoparticles in the environment is yet to be investigated and recommended as a future work. Measurement of cetane number and oxygen content in the biodiesel-nanoparticle blends are other important items for further studies.

Author Contributions: Conceptualization, A.K.H. and A.H.; methodology, A.K.H. and A.H.; validation, A.K.H. and A.H.; formal analysis, A.K.H. and A.H.; investigation, A.K.H. and A.H.; resources, A.K.H. and A.H.; data curation, A.K.H. and A.H.; writing—original draft preparation, A.K.H. and A.H.; writing—review and editing, A.K.H.; supervision, A.K.H.; project administration, A.K.H.

Funding: This research received no external funding.

Conflicts of Interest: The authors declare no conflict of interest.

\section{Nomenclature}

$\begin{array}{ll}\text { BSEC } & \text { Brake Specific Energy Consumption } \\ \text { BSFC } & \text { Brake Specific Fuel Consumption } \\ \text { BTE } & \text { Brake Thermal Efficiency } \\ \text { FFA } & \text { Free Fatty Acid } \\ \text { GHG } & \text { Greenhouse Gas } \\ \text { HHV } & \text { Higher Heating Value } \\ \text { J100 } & \text { Neat jatropha biodiesel (100\%) } \\ \text { J100A100 } & \text { Jatropha biodiesel (100\%) with } 100{\mathrm{ppm} \mathrm{Al}_{2} \mathrm{O}_{3}} \\ \text { J100A50 } & \text { Jatropha biodiesel }(100 \%) \text { with } 50 \mathrm{ppm} \mathrm{Al}_{2} \mathrm{O}_{3} \\ \text { J100C100 } & \text { Jatropha biodiesel (100\%) with } 100{\mathrm{ppm} \mathrm{CeO}_{2}} \\ \text { J100C50 } & \text { Jatropha biodiesel (100\%) with } 50 \mathrm{ppm} \mathrm{CeO}_{2} \\ \text { JBD } & \text { Jatropha Biodiesel } \\ \text { JCO } & \text { Jatropha Curcas Oil } \\ \text { IC } & \text { Internal Combustion } \\ \text { UHC } & \text { Unburnt Hydrocarbons }\end{array}$




\section{References}

1. Khoo, H.H.; Tan, R.B.H. Environmental impact evaluation of conventional fossil fuel production (oil and natural gas) and enhanced resource recovery with potential $\mathrm{CO}_{2}$ sequestration. Energy Fuels 2006, 20, 1914-1924. [CrossRef]

2. Global Emissions by Economic Sector. Available online: https://www.epa.gov/ghgemissions/globalgreenhouse-gas-emissions-data\#Trends (accessed on 17 February 2019).

3. Environmental Protection UK. Car Pollution. Environmental Protection UK, 2015. Available online: https:/ / www.environmental-protection.org.uk/policy-areas / air-quality/air-pollution-and-transport/ car-pollution/ (accessed on 20 November 2018).

4. DAWN Biofuels: A Substitute for Petroleum. Available online: https://www.dawn.com/news/266470 (accessed on 15 November 2018).

5. Conserve Energy Future. Advantages and Disadvantages of Biofuels. Conserve Energy Future. Available online: https:/ / www.conserve-energy-future.com/advantages-and-disadvantages-of-biofuels. php (accessed on 22 December 2018).

6. Hoover, F.-A.; Abraham, J. Biofuels can help solve climate change, especially with a carbon tax. Int. J. Sustain. Energy 2009, 28, 171-182. [CrossRef]

7. Giakoumis, E.G.; Sarakatsanis, C.K. A Comparative Assessment of Biodiesel Cetane Number Predictive Correlations Based on Fatty Acid Composition. Energies 2019, 12, 422. [CrossRef]

8. Kaya, T.; Kutlar, O.A.; Taskiran, O.O. Evaluation of the Effects of Biodiesel on Emissions and Performance by Comparing the Results of the New European Drive Cycle and Worldwide Harmonized Light Vehicles Test Cycle. Energies 2018, 11, 2814. [CrossRef]

9. Wan Ghazali, W.N.M.; Mamat, R.; Masjuki, H.H.; Najafi, G. Effects of biodiesel from different feedstocks on engine performance and emissions: A review. Renew. Sustain. Energy Rev. 2015, 51, 585-602. [CrossRef]

10. Mofijur, M.; Hazrat, M.A.; Rasul, M.G.; Mahmudul, H.M. Comparative Evaluation of Edible and Non-edible Oil Methyl Ester Performance in a Vehicular Engine. Energy Procedia 2015, 75, 37-43. [CrossRef]

11. Mofijur, M.; Atabani, A.E.; Masjuki, H.H.; Kalam, M.A.; Masum, B.M. A study on the effects of promising edible and non-edible biodiesel feedstocks on engine performance and emissions production: A comparative evaluation. Renew. Sustain. Energy Rev. 2013, 23, 391-401. [CrossRef]

12. Shaafi, T.; Sairam, K.; Gopinath, A.; Kumaresan, G.; Velraj, R. Effect of dispersion of various nanoadditives on the performance and emission characteristics of a CI engine fuelled with diesel, biodiesel and blends-A review. Renew. Sustain. Energy Rev. 2015, 49, 563-573. [CrossRef]

13. Saxena, V.; Kumar, N.; Saxena, V.K. A comprehensive review on combustion and stability aspects of metal nanoparticles and its additive effect on diesel and biodiesel fuelled C.I. engine. Renew. Sustain. Energy Rev. 2017, 70, 563-588. [CrossRef]

14. Aalam, C.S.; Saravanan, C.G. Effects of nano metal oxide blended Mahua biodiesel on CRDI diesel engine. Ain Shams Eng. J. 2017, 8, 689-696. [CrossRef]

15. Nanoparticles Increase Biofuel Performance. Available online: https:/ / www.sciencedaily.com/releases / 2011/04/110408075042.htm (accessed on 25 August 2018).

16. Soutter, B.W. Nanoparticles as Fuel Additives. 2012, pp. 1-3. Available online: https://www.azonano.com/ article.aspx?ArticleID=3085 (accessed on 17 February 2019).

17. Arul Mozhi Selvan, V.; Anand, R.B.; Udayakumar, M. Effects of Cerium Oxide Nanoparitcle Addition in Diesel and Diesel-Biodiesel-Ethanol Blends on the performance and emission characteristics of a C1 Engine. ARPN J. Eng. Appl. Sci. 2009, 4, 1-6.

18. Gan, Y.; Qiao, L. Combustion characteristics of fuel droplets with addition of nano and micron-sized aluminum particles. Combust. Flame 2011, 158, 354-368. [CrossRef]

19. Sadhik Basha, J.; Anand, R.B. Role of nanoadditive blended biodiesel emulsion fuel on the working characteristics of a diesel engine. J. Renew. Sustain. Energy 2011, 3. [CrossRef]

20. Saraee, H.S.; Jafarmadar, S.; Taghavifar, H.; Ashraf, S.J. Reduction of emissions and fuel consumption in a compression ignition engine using nanoparticles. Int. J. Environ. Sci. Technol. 2015, 12, 2245-2252. [CrossRef]

21. Valencia, M.; López, E.; Andrade, S.; Iris, M.L.; Hurtado, N.G.; Pérez, V.R.; García, A.G.; de Lecea, C.S.M.; Bueno López, A. Evidences of the Cerium Oxide-Catalysed DPF Regeneration in a Real Diesel Engine Exhaust. Available online: https://core.ac.uk/download/pdf/32320231.pdf (accessed on 11 February 2019). 
22. Razek, S.M.A.; Gad, M.S.; Thabet, O.M. Effect of Aluminum Oxide Nano-Particle in Jatropha Biodiesel on Performance, Emissions and Combustion Characteristics of D I Diesel Engine. Ijraset 2017, 5, 358-372. [CrossRef]

23. Ramesh, D.K.; Dhananjaya Kumar, J.L.; Hemanth Kumar, S.G.; Namith, V.; Basappa Jambagi, P.; Sharath, S. Study on effects of Alumina nanoparticles as additive with Poultry litter biodiesel on Performance, Combustion and Emission characteristic of Diesel engine. Mater. Today Proc. 2018, 5, 1114-1120. [CrossRef]

24. Ghanbari, M.; Najafi, G.; Ghobadian, B.; Yusaf, T.; Carlucci, A.P.; Kiani Deh Kiani, M. Performance and emission characteristics of a CI engine using nano particles additives in biodiesel-diesel blends and modeling with GP approach. Fuel 2017, 202, 699-716. [CrossRef]

25. Kumar, S.; Dinesha, P.; Bran, I. Influence of nanoparticles on the performance and emission characteristics of a biodiesel fuelled engine: An experimental analysis. Energy 2017, 140, 98-105. [CrossRef]

26. Chandrasekaran, V.; Arthanarisamy, M.; Nachiappan, P.; Dhanakotti, S.; Moorthy, B. The role of nano additives for biodiesel and diesel blended transportation fuels. Transp. Res. Part D Transp. Environ. 2016, 46, 145-156. [CrossRef]

27. Sadhik Basha, J. Impact of Carbon Nanotubes and Di-Ethyl Ether as additives with biodiesel emulsion fuels in a diesel engine-An experimental investigation. J. Energy Inst. 2018, 91, 289-303. [CrossRef]

28. Heydari-Maleney, K.; Taghizadeh-Alisaraei, A.; Ghobadian, B.; Abbaszadeh-Mayvan, A. Analyzing and evaluation of carbon nanotubes additives to diesohol-B2 fuels on performance and emission of diesel engines. Fuel 2017, 196, 110-123. [CrossRef]

29. Hoseini, S.S.; Najafi, G.; Ghobadian, B.; Mamat, R.; Ebadi, M.T.; Yusaf, T. Novel environmentally friendly fuel: The effects of nanographene oxide additives on the performance and emission characteristics of diesel engines fuelled with Ailanthus altissima biodiesel. Renew. Energy 2018, 125, 283-294. [CrossRef]

30. Dhinesh, B.; Maria Ambrose Raj, Y.; Kalaiselvan, C.; KrishnaMoorthy, R. A numerical and experimental assessment of a coated diesel engine powered by high-performance nano biofuel. Energy Convers. Manag. 2018, 171, 815-824. [CrossRef]

31. Dhinesh, B.; Niruban Bharathi, R.; Isaac JoshuaRamesh Lalvani, J.; Parthasarathy, M.; Annamalai, K. An experimental analysis on the influence of fuel borne additives on the single cylinder diesel engine powered by Cymbopogon flexuosus biofuel. J. Energy Inst. 2017, 90, 634-645. [CrossRef]

32. Wu, Q.; Xie, X.; Wang, Y.; Roskilly, T. Effect of carbon coated aluminum nanoparticles as additive to biodiesel-diesel blends on performance and emission characteristics of diesel engine. Appl. Energy 2018, 221, 597-604. [CrossRef]

33. Prabu, A. Nanoparticles as additive in biodiesel on the working characteristics of a DI diesel engine. Ain Shams Eng. J. 2017, 9, 2343-2349. [CrossRef]

34. Najafi, G. Diesel engine combustion characteristics using nano-particles in biodieseldiesel blends. Fuel 2018, 212, 668-678. [CrossRef]

35. Chhetri, A.B.; Tango, M.S.; Budge, S.M.; Watts, K.C.; Islam, M.R. Non-edible plant oils as new sources for biodiesel production. Int. J. Mol. Sci. 2008, 9, 169-180. [CrossRef] [PubMed]

36. Banković-Ilić, I.B.; Stamenković, O.S.; Veljković, V.B.; Stamenkovi, O.S.; Veljkovi, V.B.; Bankovi, I.B. Biodiesel production from non-edible plant oils. Renew. Sustain. Energy Rev. 2012, 16, 3621-3647. [CrossRef]

37. Hossain, A.K.; Hussain, A. Effect of Nanoparticle on Combustion and Emission Characteristics of neat Jatropha Biodiesel (Paper No 0552-1). In Proceedings of the 13th SDEWES Conference, Palermo, Italy, 30 September-4 October 2018 .

38. Heroor, S.H.; Bharadwaj, S.D.R. Production of Bio-fuel from Crude Neem Oil and its Performance. Int. J. Environ. Eng. Manag. 2013, 4, 425-432.

39. Chongkhong, S.; Kanjaikaew, U.; Tongurai, C.; Yai, H. A Review of FFA Esterification for Biodiesel Production. 10th Int. PSU Eng. Conf. 2012, 1, 1-5.

40. Patil, P.D.; Deng, S. Optimization of biodiesel production: Transesterification of edible and non-edible vegetable oils. Fuel 2009, 88, 1302-1306. [CrossRef]

41. Singh, R.; Padhi, S. Characterization of jatropha oil for tha preparation of biodiesel. Nat. Prod. Radiance 2009, $8,127-132$.

42. Kumar Tiwari, A.; Kumar, A.; Raheman, H. Biodiesel production from jatropha oil (Jatropha curcas) with high free fatty acids: An optimized process. Biomass Bioenergy 2007, 31, 569-575. [CrossRef]

43. Ma, F.; Hanna, M.A. Biodiesel production: A review. Bioresour. Technol. 1999, 70, 1-15. [CrossRef] 
44. Kumar, A. Effects of Cerium Oxide Nanoparticle on Compression Ignintion Engine Performance and Emission Charachteristic when Using Water Diesel Emuslion. Master's Thesis, Thapar University, Patiala, India, 2014.

45. Enweremadu, C.C.; Rutto, H.L. Combustion, emission and engine performance characteristics of used cooking oil biodiesel-A review. Renew. Sustain. Energy Rev. 2010, 14, 2863-2873. [CrossRef]

46. Dhar, A.; Agarwal, A.K. Performance, emissions and combustion characteristics of Karanja biodiesel in a transportation engine. Fuel 2014, 119, 70-80. [CrossRef]

47. Bakeas, E.; Karavalakis, G.; Stournas, S. Biodiesel emissions profile in modern diesel vehicles. Part 1: Effect of biodiesel origin on the criteria emissions. Sci. Total Environ. 2011, 409, 1670-1676. [CrossRef] [PubMed]

48. Qi, D.H.; Chen, H.; Geng, L.M.; Bian, Y.Z.; Ren, X.C. Performance and combustion characteristics of biodiesel-diesel-methanol blend fuelled engine. Appl. Energy 2010, 87, 1679-1686. [CrossRef]

49. Kadarohman, A.; Hernani; Rohman, I.; Kusrini, R.; Astuti, R.M. Combustion characteristics of diesel fuel on one cylinder diesel engine using clove oil, eugenol, and eugenyl acetate as fuel bio-additives. Fuel 2012, 98, 73-79. [CrossRef]

50. Singh, A.P.; Agarwal, A.K. Combustion characteristics of diesel HCCI engine: An experimental investigation using external mixture formation technique. Appl. Energy 2012, 99, 116-125. [CrossRef]

(c) 2019 by the authors. Licensee MDPI, Basel, Switzerland. This article is an open access article distributed under the terms and conditions of the Creative Commons Attribution (CC BY) license (http:/ / creativecommons.org/licenses/by/4.0/). 